\title{
Green and efficient synthesis of aryl/alkylbis(indolyl)methanes using Expanded Perlite-PPA as a heterogeneous solid acid catalyst in aqueous media
}

\author{
MARZIEH ESMAIELPOUR, BATOOL AKHLAGHINIA* and ROYA JAHANSHAHI \\ Department of Chemistry, Faculty of Sciences, Ferdowsi University of Mashhad, Mashhad 9177948974, Iran \\ Email: akhlaghinia@um.ac.ir
}

MS received 10 October 2016; revised 19 December 2016; accepted 3 February 2017

\begin{abstract}
Expanded Perlite-Polyphosphoric acid (EP-PPA) as a novel, efficient, recyclable and eco-benign heterogeneous catalyst has been applied for the green and rapid synthesis of aryl/alkylbis(indolyl)methanes, in water, in good to excellent yields. The catalyst was characterized by XRF, FT-IR, TGA/DTG, ICP-OES, SEM$\mathrm{EDX}$ and $\mathrm{pH}$ analysis. Importantly, the newly synthesized heterogeneous solid acid catalyst can be recovered and reused six times without any significant loss in its catalytic potential. The remarkable features of the present methodology are high conversions, shorter reaction times, cleaner reaction profiles and simple work-up procedures.
\end{abstract}

Keywords. Expanded Perlite-PPA; aryl/alkylbis(indolyl)methanes; carbonyl compounds; heterogeneous catalyst.

\section{Introduction}

Indole and its natural and synthetic derivatives are important heterocyclic compounds due to their wide-ranging biological and pharmaceutical activities. ${ }^{1-3}$ Among the different indole derivatives, aryl/alkylbis(indolyl)methanes are well-known as an old but privileged class of bioactive metabolites, ${ }^{4-6}$ due to their representation in natural products ${ }^{7}$ and extensive applications in pharmaceuticals. ${ }^{8}$ Over the past few years, a variety of bis (indolyl)methanes have been isolated from earthly and marine natural sources such as parasitic bacteria, tunicates, and sponges, ${ }^{3,9}$ and these have exhibited antibacterial activity against Staphylococcus aureus, S. albus and Bacillus subtilis, ${ }^{10}$ in addition to anti-inflammatory and antibacterial activity. ${ }^{11}$

Bis(indolyl)methanes are the most active cruciferous substances for promoting beneficial estrogen metabolism. ${ }^{12}$ These can be effective in the prevention of cancer and moreover may normalize the abnormal cell growth associated with cervical dysplasia. ${ }^{13}$ Therefore, the synthesis of this class of compounds is of considerable interest for synthetic organic chemists (towards the development of new protocols) and biologists. To seek efficient and convenient synthetic routes of bis(indolyl)methanes, great efforts have been made.

Traditionally, bis(indolyl)methanes have been synthesized by electrophilic substitution reaction of indoles

\footnotetext{
*For correspondence
}

with carbonyl compounds, catalyzed by either protic or Lewis acids ${ }^{14,15}$ such as montmorillonite clay, ${ }^{16,17}$ oxone, ${ }^{18} \mathrm{NH}_{4} \mathrm{Cl},{ }^{19}$ cellulose sulfuric acid, ${ }^{20}$ ionic liquid, ${ }^{21}$ oxalic acid, ${ }^{22} \mathrm{La}(\mathrm{OTf})_{3},{ }^{23} \mathrm{In}(\mathrm{OTf})_{3},{ }^{24}$ zirconium tetrakis(dodecyl sulfate), ${ }^{25} \mathrm{H}_{6} \mathrm{P}_{2} \mathrm{~W}_{18} \mathrm{O}_{62},{ }^{26}$ phosphated zirconia, ${ }^{27}$ 12-tungstophosphoric acid supported on zirconia, ${ }^{28} \mathrm{GaCl}_{3},{ }^{29} \mathrm{ZnO},{ }^{30} \mathrm{FeCl}_{3} \cdot 6 \mathrm{H}_{2} \mathrm{O},{ }^{31} \mathrm{Al}_{2} \mathrm{O}_{3},{ }^{32}$ zirconyldodecylsulfate, ${ }^{33} \mathrm{I}_{2},{ }^{34}$ silica gel, ${ }^{35}$ pyridinium tribromide, ${ }^{36} \mathrm{SiO}_{2} / \mathrm{AlCl}_{3},{ }^{37}$ Iron(III) dodecyl sulfate, ${ }^{38}$ PPA-SiO ${ }_{2},{ }^{39,40}$ ammonium niobium oxalate and tetrabutylammonium hydrogen sulfate. ${ }^{41}$ The reported methods indicate that the catalysts commonly used for such a transformation, are generally associated with one or more of the following disadvantages such as high toxicity, high cost, difficulty of handling, low thermal stability and un-recyclability. In addition to these drawbacks, tedious methods required for the separation of the products, along with using the environmentally harmful organic solvents in some of these approaches, are definitely far from the concept of "Green Chemistry". Also, because of either the strong adsorption or polymerization of indole by Lewis acid sites, these methods consume more reactants than the required amounts, according to the stoichiometries of the reactions. ${ }^{42}$ Likewise, many Lewis acids are deactivated or sometimes decomposed by nitrogen-containing reactants, which would lead to use of more than stoichiometric amounts of Lewis acids, besides the generation of harmful wastes, which would pose environmental problems. ${ }^{42}$ Furthermore, although solid acid catalysts promote the synthesis 
of bis(indolyl)methane, some of them require very high temperature for reactivation. ${ }^{43}$

Keeping in view the increasing importance of bis(indolyl)methane derivatives in pharmaceutical and industrial chemistry, there is still much demand to develop a better catalytic process, that would abate the environmental impact of the pollution resulting from the above mentioned methods reported for the synthesis of such significant scaffolds.

Polyphosphoric acid (PPA) has been employed as an efficient protic acid catalyst for numerous organic reactions. ${ }^{44}$ Nevertheless, the difficulty of PPA handling, due to its viscous nature, has limited its application. To surmount this problem and in continuation of our ongoing research in synthetic organic chemistry, for the development of efficient and environmentally benign heterogeneous catalysts, ${ }^{45}$ herein, we report Expanded Perlite-PPA (EP-PPA), as a novel, green and efficient heterogeneous catalyst (Scheme 1). The catalytic activity of EP-PPA was verified by the synthesis of aryl/alkylbis(indolyl)methanes through the one-pot reaction of indole and carbonyl compounds, in water. Importantly, this distinguished catalyst is easy to prepare and handle and could be separated simply by filtration and also recycled for six times without significant loss of its catalytic activity.

\section{Experimental}

\subsection{Materials}

All chemical reagents and solvents were purchased from Merck and Sigma-Aldrich and were used as received without further purification. Expanded Perlite was obtained from Iran: Birjand resources.

\subsection{Instrumentation analysis}

The purity determination of the products and the progress of the reactions were monitored by TLC on silica gel polygram STL G/UV 254 plates. The melting points of products were determined with an Electrothermal Type 9100 melting point apparatus. The FT-IR spectra were recorded on an Avatar 370 FT-IR Therma Nicolet spectrometer. The NMR spectra were recorded on Brucker Avance 300 and $500 \mathrm{MHz}$ instruments in $\mathrm{CDCl}_{3}$ and DMSO- $d_{6}$. Mass spectra were recorded with a Shimadzu GC-MS-QP5050 and CH7A Varianmat Bremem instrument at $70 \mathrm{eV}$, in $\mathrm{m} / \mathrm{z}$ (rel \%). Thermogravimetric analyses (TGA and DTG) were carried out using a Shimadzu Thermogravimetric Analyzer (TG-50) in the temperature range of $25-900^{\circ} \mathrm{C}$ at a heating rate of $10^{\circ} \mathrm{C} \mathrm{min}^{-1}$, under air atmosphere. Inductively coupled plasma optical emission spectroscopy (ICPOES) was carried out on a 76004555 SPECTRO ARCOS ICP-OES analyzer. SEM images were recorded using a Leo1450 VP scanning electron microscope equipped with an SC7620 energy-dispersive X-ray spectrometer (EDX), presenting a $133 \mathrm{eV}$ resolution at $20 \mathrm{kV}$. The chemical compositions of the expanded perlite were specified with X-ray fluorescence spectroscopy (XRF), using BRUKER axs-S4 EXPLORER spectrometer. All of the obtained products are known compounds and their physical (color, melting points) and spectral (mass spectrometry) data were found to be identical with those of authentic compounds. The selected compounds were further identified by FT-IR, ${ }^{1} \mathrm{H}$ NMR and ${ }^{13} \mathrm{C}$ NMR spectroscopy which compared with literature data.

\subsection{Preparation of EP-PPA}

A mixture of polyphosphoric acid $(2.1 \mathrm{~g})$ in $\mathrm{CHCl}_{3}(100 \mathrm{~mL})$ was stirred at $50^{\circ} \mathrm{C}$ for $1 \mathrm{~h}$. Expanded Perlite $(4.9 \mathrm{~g})$ was added to the resulting solution and the mixture was stirred vigorously. After $1 \mathrm{~h}, \mathrm{CHCl}_{3}$ was removed under reduced pressure and the resulting solid was dried in vacuo at room temperature for $3 \mathrm{~h}$.

\subsection{Typical procedure for the synthesis of 3,3'- (phenylmethylene)bis(1H-indole) in the presence of EP-PPA}

To a mixture of indole $(2 \mathrm{mmol}, 0.234 \mathrm{~g})$ and benzaldehyde $(1 \mathrm{mmol}, 0.106 \mathrm{~g})$ in $\mathrm{H}_{2} \mathrm{O}(3 \mathrm{~mL})$, EP-PPA $(0.04 \mathrm{~g})$ was added. The mixture was allowed to stir at $60^{\circ} \mathrm{C}$. Upon completion of the reaction (monitored by TLC analysis), the catalyst was separated by filtration. After the filtration, $\mathrm{H}_{2} \mathrm{O}$ $(10 \mathrm{~mL})$ was added and the product was extracted into ethyl acetate $(3 \times 15 \mathrm{~mL})$. The combined organic layer was dried over anhydrous $\mathrm{Na}_{2} \mathrm{SO}_{4}$ and then evaporated under vacuum to afford the crude product, which was further purified by thin layer chromatography (preparative TLC was carried out using a Merck GF 254 silica gel on a glass support)

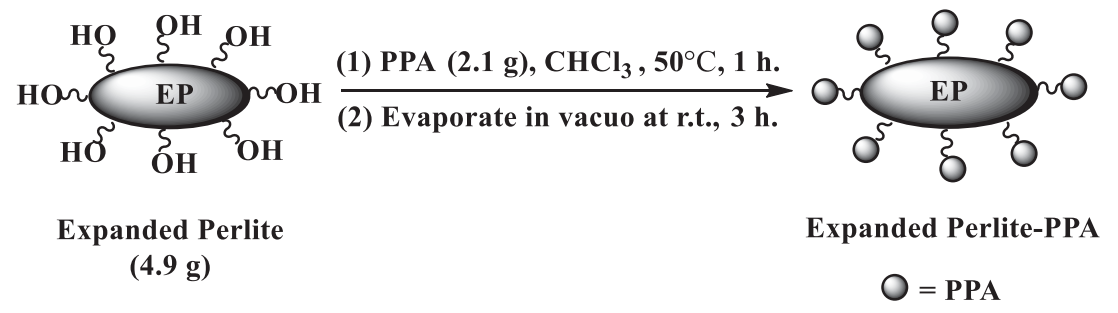

Scheme 1. Preparation of Expanded Perlite-PPA. 
using $n$-hexane:ethyl acetate $(3: 1)$ as eluent. The pure $3,3^{\prime}$ (phenylmethylene)bis( $1 H$-indole) was obtained in $98 \%$ yield (0.315 g).

\section{Results and Discussion}

Expanded Perlite is a green and inexpensive mixture of mineral oxides, which mainly consists of silica and alumina ${ }^{46}$ (Table 1). The exclusive features of Expanded Perlite include high porosity besides strong adsorbability, thermal and chemical stability, low toxicity, low cost, non-corrosiveness and ease of handling. ${ }^{47}$ These distinctive properties make the Expanded Perlite an excellent support for the preparation of heterogeneous catalysts. ${ }^{48}$ EP-PPA was prepared by the concise route outlined in Scheme 1 . The current method has many advantages such as simplification of the catalyst system and its synthesis, as well as using an inexpensive and available precursor. The assynthesized white heterogeneous, non-hygroscopic catalyst is very stable under the reaction conditions. This new catalyst was characterized by different techniques such as fourier transform infrared spectroscopy (FT-IR), thermogravimetric/differential thermogravimetric analysis (TG/DTG), scanning electron microscopy (SEM), energy-dispersive X-ray spectroscopy (EDX), Inductively coupled plasma optical emission spectroscopy (ICP-OES) and $\mathrm{pH}$ analysis. The obtained results from these techniques confirmed the successful preparation of the new catalyst.

\subsection{Characterization of the catalyst}

3.1a FT-IR spectroscopy of the catalyst: FT-IR spectra of Expanded Perlite and EP-PPA are shown in Figure 1. As it is obvious in Figure 1a, there are five significant absorption bands in the infrared spectrum of Expanded Perlite. ${ }^{49}$ The indicative bands corresponding to the stretching and bending modes of hydroxyl groups on the surface of Expanded Perlite (mainly $\mathrm{Si}-\mathrm{OH}$ groups) and the adsorbed water molecules are depicted at $3439 \mathrm{~cm}^{-1}$ and $1625 \mathrm{~cm}^{-1}$, respectively. ${ }^{48 \mathrm{~b}}$ The peaks at $1044 \mathrm{~cm}^{-1}$ and $791 \mathrm{~cm}^{-1}$ are assigned to $\mathrm{Si}-\mathrm{O}$ stretching vibrations of $\mathrm{Si}-\mathrm{O}-\mathrm{Si}$ and $\mathrm{Si}-\mathrm{O}-\mathrm{Al}$, respectively. ${ }^{50}$ Moreover, $\mathrm{O}-\mathrm{Si}-\mathrm{O}$ bending vibrations are evident at about $463 \mathrm{~cm}^{-1} .{ }^{49}$ In the spectrum of

Table 1. The chemical composition of Expanded Perlite based on XRF analysis.

\begin{tabular}{lccccccc}
\hline Constituent & $\mathrm{SiO}_{2}$ & $\mathrm{Al}_{2} \mathrm{O}_{3}$ & $\mathrm{~K}_{2} \mathrm{O}$ & $\mathrm{Fe}_{2} \mathrm{O}_{3}$ & $\mathrm{Na}_{2} \mathrm{O}$ & $\mathrm{CaO}$ & $\mathrm{MgO}$ \\
\hline Percentage & 75.22 & 12.77 & 5.18 & 0.74 & 2.52 & 0.60 & 0.22 \\
Constituent & $\mathrm{BaO}$ & $\mathrm{SO}_{3}$ & $\mathrm{ZrO}_{2}$ & $\mathrm{TiO}_{2}$ & $\mathrm{Rb}_{2} \mathrm{O}$ & $\mathrm{SrO}$ & $\mathrm{MnO}$ \\
Percentage & 0.08 & 0.06 & 0.01 & 0.11 & 0.01 & 0.01 & 0.06 \\
\hline
\end{tabular}

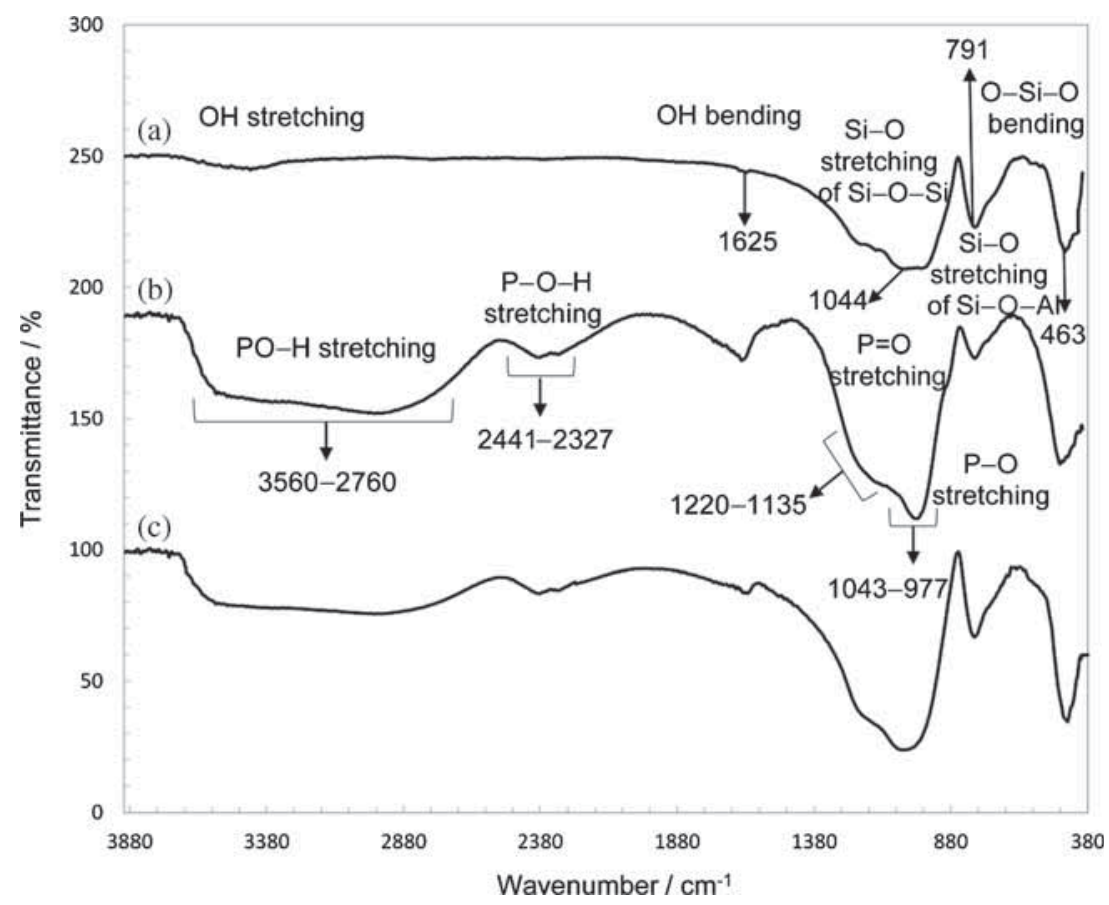

Figure 1. FT-IR spectrum of, (a) Expanded Perlite; (b) EP-PPA and (c) 6th recovered EP-PPA. 
EP-PPA, absorption band at about $1043-977 \mathrm{~cm}^{-1}$ is ascribed to $\mathrm{P}-\mathrm{O}$ stretching vibration of PPA. ${ }^{51}$ Another band at around $1220-1135 \mathrm{~cm}^{-1}$ is related to stretching vibration of $\mathrm{P}=\mathrm{O}$ bond. ${ }^{51}$ In addition, the $\mathrm{P}-\mathrm{O}-\mathrm{H}$ stretching modes are observed as broad peaks at about $2441-2327 \mathrm{~cm}^{-1} .^{51}$ It is worth to note that the intensity of O-H stretching vibration from 3300 to $3450 \mathrm{~cm}^{-1}$ in the case of EP-PPA is more than that of Expanded Perlite, which clearly indicates the incorporation of PPA on the Expanded Perlite surface.

3.1b TGA of the catalyst: Thermogravimetric (TG) and differential thermogravimetric (DTG) analysis were used to investigate the thermal stability of the acidic catalyst. TGA thermograms of EP-PPA and bare Expanded Perlite are shown in Figure 2. The results demonstrate that the Expanded Perlite (Figure 2a) showed an initial weight loss, occurring below $120^{\circ} \mathrm{C}$ (about $0.5 \%$ ) which is attributed to the loss of the physically adsorbed water molecules. After that, Expanded Perlite had a steady weight loss at temperature lower than $600^{\circ} \mathrm{C}$ (about 3\%), which presumably corresponds to the dehydroxylation of Expanded Perlite. ${ }^{52}$

TGA thermogram of EP-PPA (Figure 2b) shows initial weight loss below $200^{\circ} \mathrm{C}$, which is due to the absorbed water molecules on the Expanded Perlite surface. The second step involves the decomposition of PPA, which started after $200^{\circ} \mathrm{C}$ and continued up to $600^{\circ} \mathrm{C}$. According to the TGA, the amount of polyphosphoric acid supported on the Expanded Perlite is estimated to be $14 \%$. 3.1c pH analysis of the catalyst: The amount of acidic sites in EP-PPA was determined by back-titration analysis of the catalyst, wherein $100 \mathrm{mg}$ of the catalyst was stirred with sodium hydroxide solution $(0.1 \mathrm{~N}, 15 \mathrm{ml})$ at room temperature, for $12 \mathrm{~h}$. Afterwards, the suspension was filtered and the filtrate was neutralized using a standard solution of $\mathrm{HCl}(0.1 \mathrm{M})$. The required volume of $\mathrm{HCl}$ to reach the equivalence point of titration was $7.3 \mathrm{ml}$. Accordingly, the number of acidic sites for EPPPA was found to be $4.7 \mathrm{mmol} \mathrm{g}^{-1}$. Furthermore, on the basis of ICP-OES analysis, the total amount of grafted $\mathrm{P}$ was calculated to be $2.48 \mathrm{mmol} \mathrm{g}^{-1}$, which matched well with the results evaluated by TGA and $\mathrm{pH}$ analysis.

3.1d SEM analysis of the catalyst: Selected SEM images for the Expanded Perlite and EP-PPA, were used to study the structure and morphology of the catalyst (Figure 3). It is clear that the morphology of Expanded Perlite is a layered porous structure, which remains constant after the immobilization of PPA on its surface.

3.1e EDX analysis of the catalyst: Figure 4 depicts the elemental components of Expanded Perlite and EP-PPA by the energy-dispersive X-ray spectroscopy (EDX). As can be seen in Figure 4, the presence of C, O, $\mathrm{Na}, \mathrm{Al}, \mathrm{Si}$, and $\mathrm{K}$ elements are evident in the EDX analysis of both Expanded Perlite and Expanded PerlitePPA. The existence of P element in the EDX analysis of EP-PPA, confirms the successful immobilization of PPA on the Expanded Perlite.

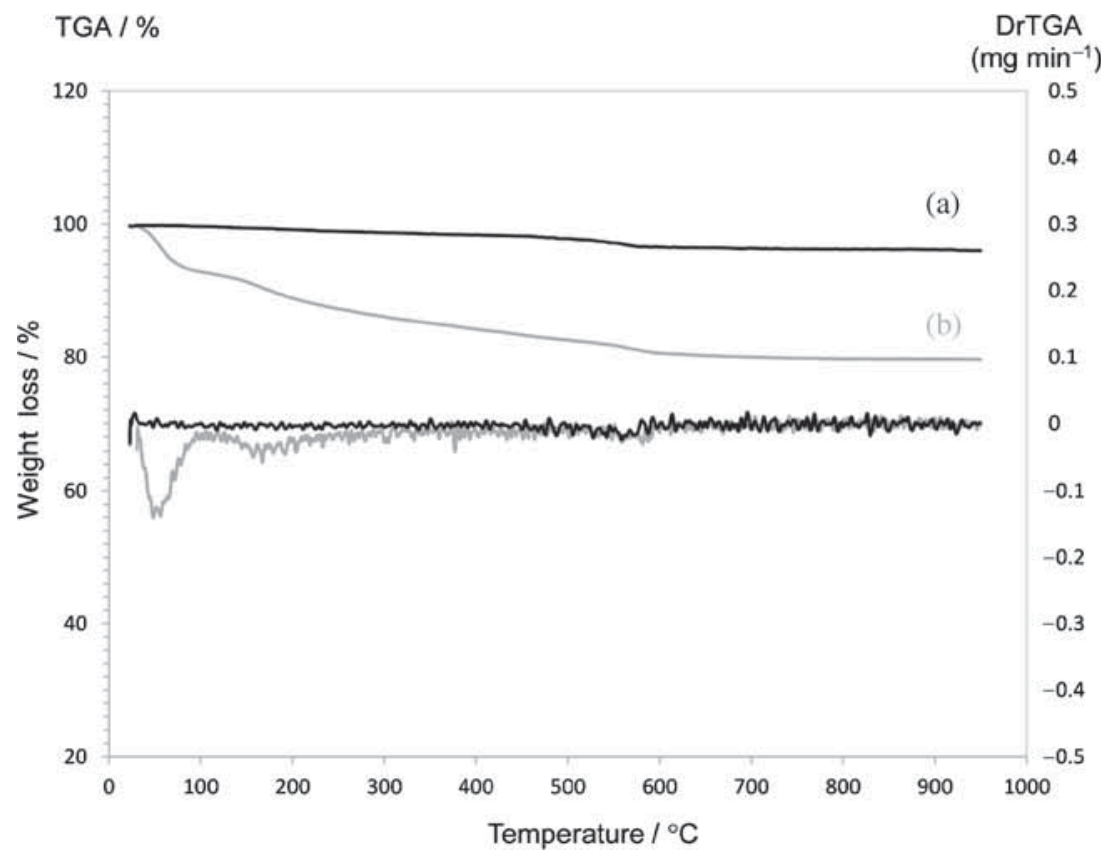

Scheme 2. TG/DTG thermograms of (a) Expanded Perlite and (b) EP-PPA. 

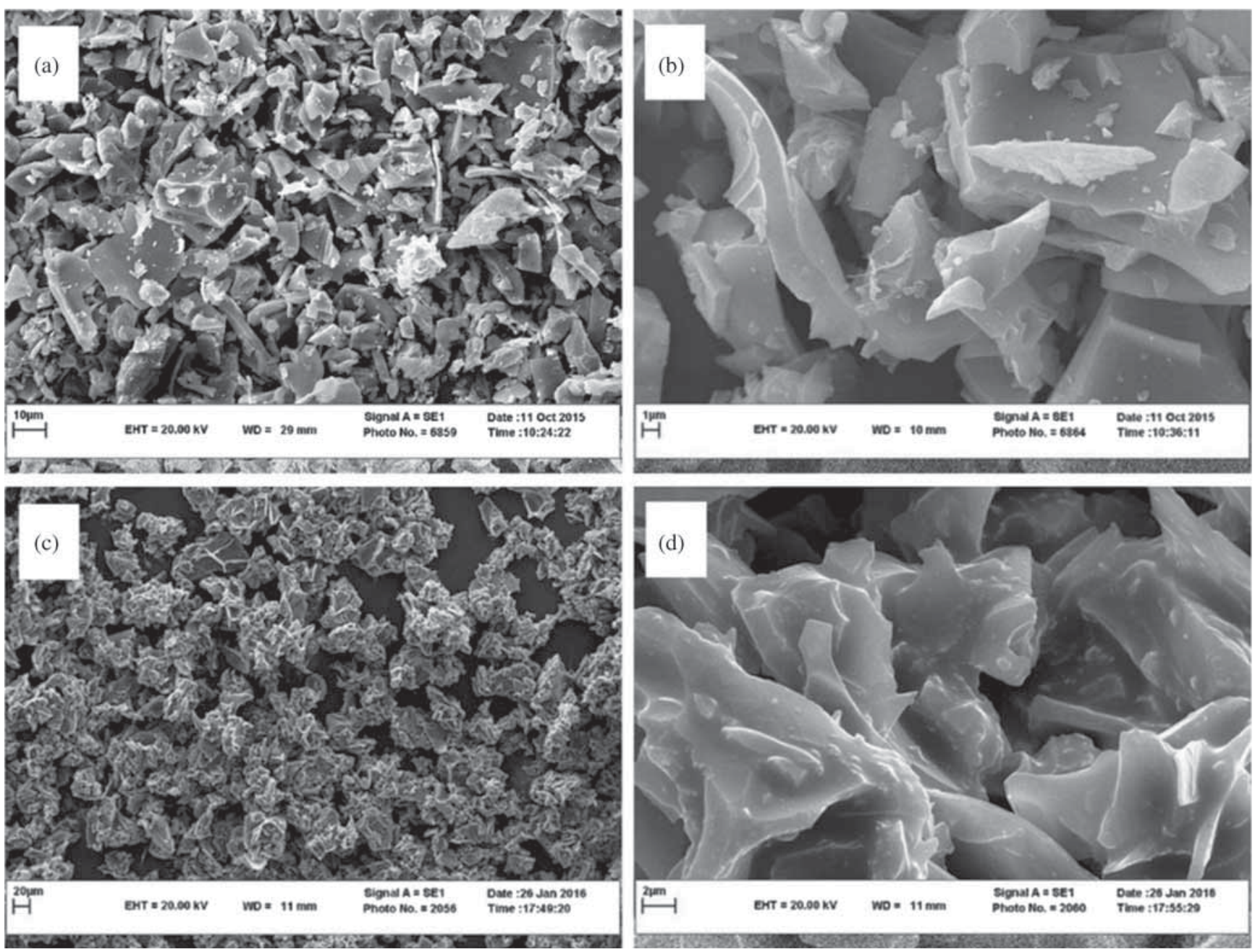

Scheme 3. SEM images of Expanded Perlite (a, b) and EP-PPA (c, d).

\subsection{Catalytic synthesis of aryl/alkylbis(indolyl)methane derivatives}

In the present study, a series of bis(indolyl)methanes were prepared by the condensation of indole (1), with different carbonyl compounds (2) in the presence of EP-PPA, as heterogeneous green catalyst (Scheme 2). The reactions proceeded efficiently to afford the desired bis(indolyl)methanes (3a-x) in good to excellent yields.

At the outset, the reaction between benzaldehyde ( $1 \mathrm{mmol})$ and indole $(2 \mathrm{mmol})$ was studied as a model reaction from the viewpoint of temperature, solvent, and the amounts of catalyst (Table 2). It is well-known that indole is not active enough in the Friedel-Crafts alkylations, without using any catalyst (Table 2, entry 1). So, choosing a suitable catalyst is crucial for the highly efficient alkylation of indole with benzaldehyde. Therefore, PPA, Expanded Perlite, and EP-PPA were examined on the model reaction at $80^{\circ} \mathrm{C}$, under solventfree condition (Table 2, entries 2-4). It is clear that PPA by itself was not effective for this transformation, which is certainly related to the sticky state of PPA in the solvent free condition at $80^{\circ} \mathrm{C}$, that has disrupted the magnetic stirring during the reaction. However, in the presence of Expanded Perlite and EP-PPA, the corresponding bis(indolyl)methane was obtained in $40 \%$ and $70 \%$ yields, respectively. As can be seen, EPPPA afforded an excellent yield of product in a short reaction time, in $\mathrm{H}_{2} \mathrm{O}$ (Table 2, entry 5). To improve the bis(indolyl)methane formation, at the same reaction conditions, the effect of temperature and catalyst amount was studied and we found that the best result was acquired at $60^{\circ} \mathrm{C}$ by applying $0.04 \mathrm{~g}$ of EP-PPA (Table 2, entries 6-9). In an effort to develop still better reaction conditions, the reaction was examined in $\mathrm{H}_{2} \mathrm{O} / \mathrm{C}_{2} \mathrm{H}_{5} \mathrm{OH}(1: 1, \mathrm{v}: \mathrm{v})$ and $\mathrm{C}_{2} \mathrm{H}_{5} \mathrm{OH}$ as solvent (Table 2, entries 10-11). In the presence of these solvents, the reaction was sluggish. As shown in Table 2, $\mathrm{H}_{2} \mathrm{O}$ was found to be the solvent of choice for the preparation of 3,3'-(phenylmethylene)bis( $1 H$-indole), in the presence of EP-PPA. Performing the organic reactions in aqueous media has attracted much attention owing to 


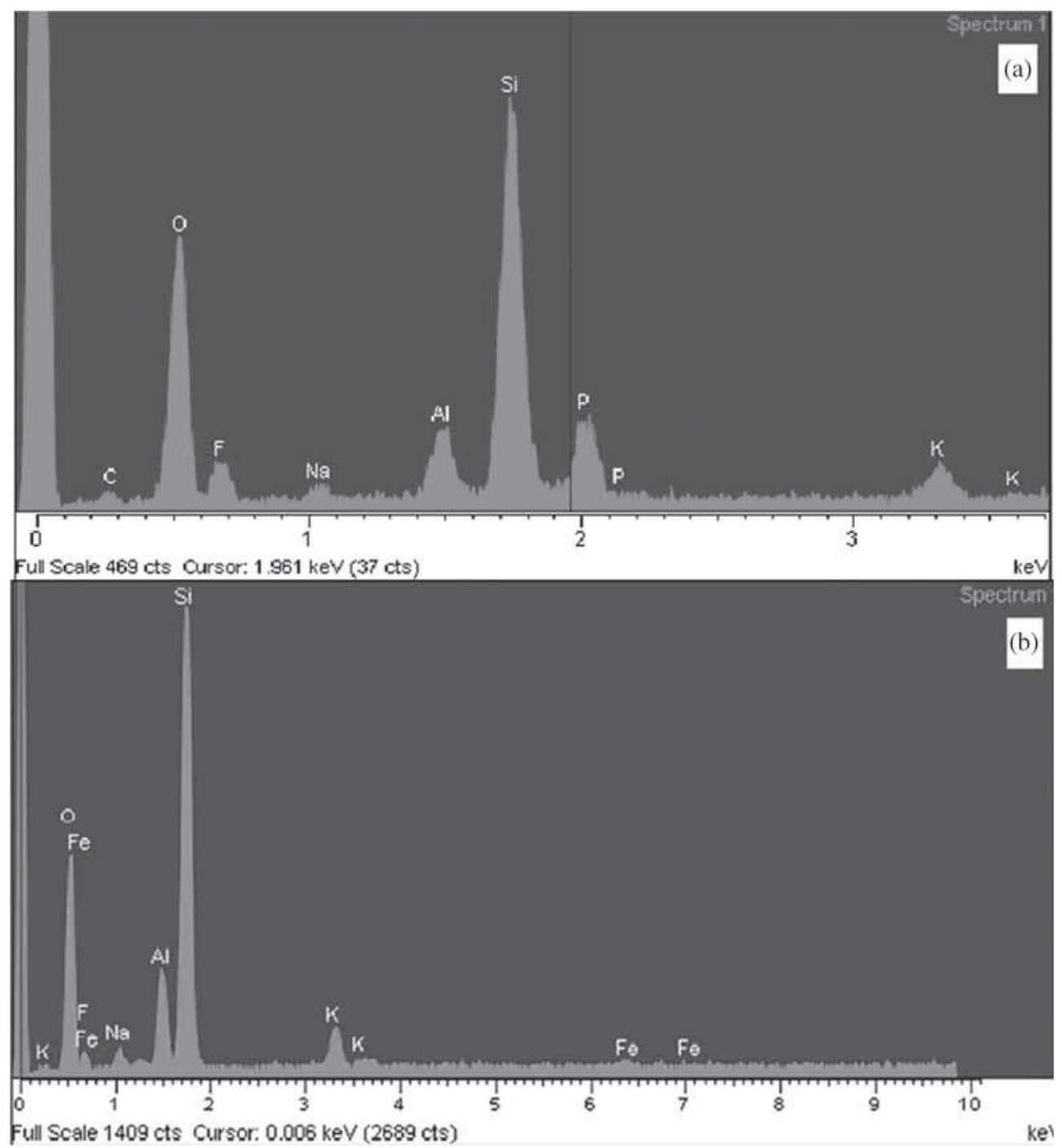

Scheme 4. EDX analysis of (a) Expanded Perlite and (b) EP-PPA.

the wonderful properties of water. Considering the significantly safe, cheap, non-toxic and environmentally friendly nature of water compared to organic solvents, it would be one of the best and greenest reaction media in organic synthesis. ${ }^{53}$

In order to emphasize the efficiency of EP-PPA in comparison with PPA and Expanded Perlite in aqueous media, the reaction was performed in the absence of the catalyst and in the presence of PPA and Expanded Perlite (in $\mathrm{H}_{2} \mathrm{O}$ at $60^{\circ} \mathrm{C}$ ) (Table 2, entries 12-14). In all cases, the product yield was not convincing.
With these impressive results in hand, to investigate the scope of this new methodology, the reaction was extended through the condensation of indole with various carbonyl compounds and the results are summarized in Table 3. It can be seen that a wide range of aromatic aldehydes can effectively react with indole to give the corresponding products. However, the nature of substitution on the aromatic ring showed some effect on the reaction progress. Aromatic aldehydes bearing electron-withdrawing groups, provided the desired products in excellent yields witin shorter reaction times,

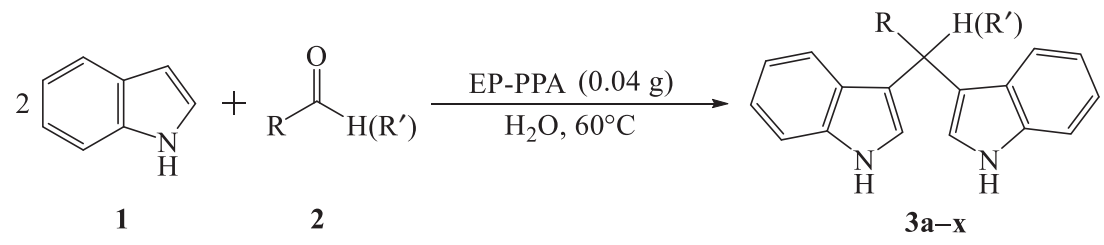

Scheme 2. Synthesis of aryl/alkylbis(indolyl)methane derivatives in the presence of EP-PPA. 
Table 2. Synthesis of 3,3'-(phenylmethylene)bis( $1 H$-indole) under different reaction conditions.

\begin{tabular}{lccccc}
\hline Entry & Catalyst/g & Solvent & Temperature/ ${ }^{\circ} \mathrm{C}$ & Time/min & Isolated yield/\% \\
\hline 1 & 0 & - & 80 & $10 / 24 \mathrm{~h}$ & $0 / 0$ \\
$2^{\mathrm{a}}$ & 0.05 & - & 80 & 30 & 0 \\
$3^{\mathrm{b}}$ & 0.05 & - & 80 & 60 & 40 \\
4 & 0.05 & - & 80 & 15 & 70 \\
5 & 0.05 & $\mathrm{H}_{2} \mathrm{O}$ & 80 & 10 & 98 \\
6 & 0.04 & $\mathrm{H}_{2} \mathrm{O}$ & 80 & 10 & 98 \\
7 & 0.04 & $\mathrm{H}_{2} \mathrm{O}$ & 70 & 10 & 98 \\
8 & 0.04 & $\mathrm{H}_{2} \mathrm{O}$ & 60 & 10 & 98 \\
9 & 0.03 & $\mathrm{H}_{2} \mathrm{O}$ & 60 & 20 & 60 \\
10 & 0.04 & $\mathrm{H}_{2} \mathrm{O} / \mathrm{C}_{2} \mathrm{H}_{5} \mathrm{OH}$ & 60 & 15 & 75 \\
11 & 0.04 & $\mathrm{C}_{2} \mathrm{H}_{5} \mathrm{OH}$ & 60 & 15 & 50 \\
12 & 0 & $\mathrm{H}_{2} \mathrm{O}$ & 60 & 15 & 0 \\
$13^{\mathrm{c}}$ & 0.05 & $\mathrm{H}_{2} \mathrm{O}$ & 60 & 15 & 40 \\
$14^{\mathrm{d}}$ & 0.05 & $\mathrm{H}_{2} \mathrm{O}$ & 60 & 15 & 35 \\
\hline
\end{tabular}

${ }^{a}$ The reaction was performed in the presence of PPA under the solvent-free condition. ${ }^{\mathrm{b}}$ The reaction was performed in the presence of Expanded Perlite under the solventfree condition.

${ }^{c}$ The reaction was performed in the presence of PPA in $\mathrm{H}_{2} \mathrm{O}$.

${ }^{\mathrm{d}}$ The reaction was performed in the presence of Expanded Perlite in $\mathrm{H}_{2} \mathrm{O}$.

wheras the condensation reaction with aldehydes having electron-donating groups took a longer time, albeit good yield of the products were obtained (Table 3, entries 1-10 vs. 11-16). Heteroaromatic aldehydes such as thiophene-2-carbaldehyde and pyridine-3-carboxaldehyde were also suitable substrates in this protocol,

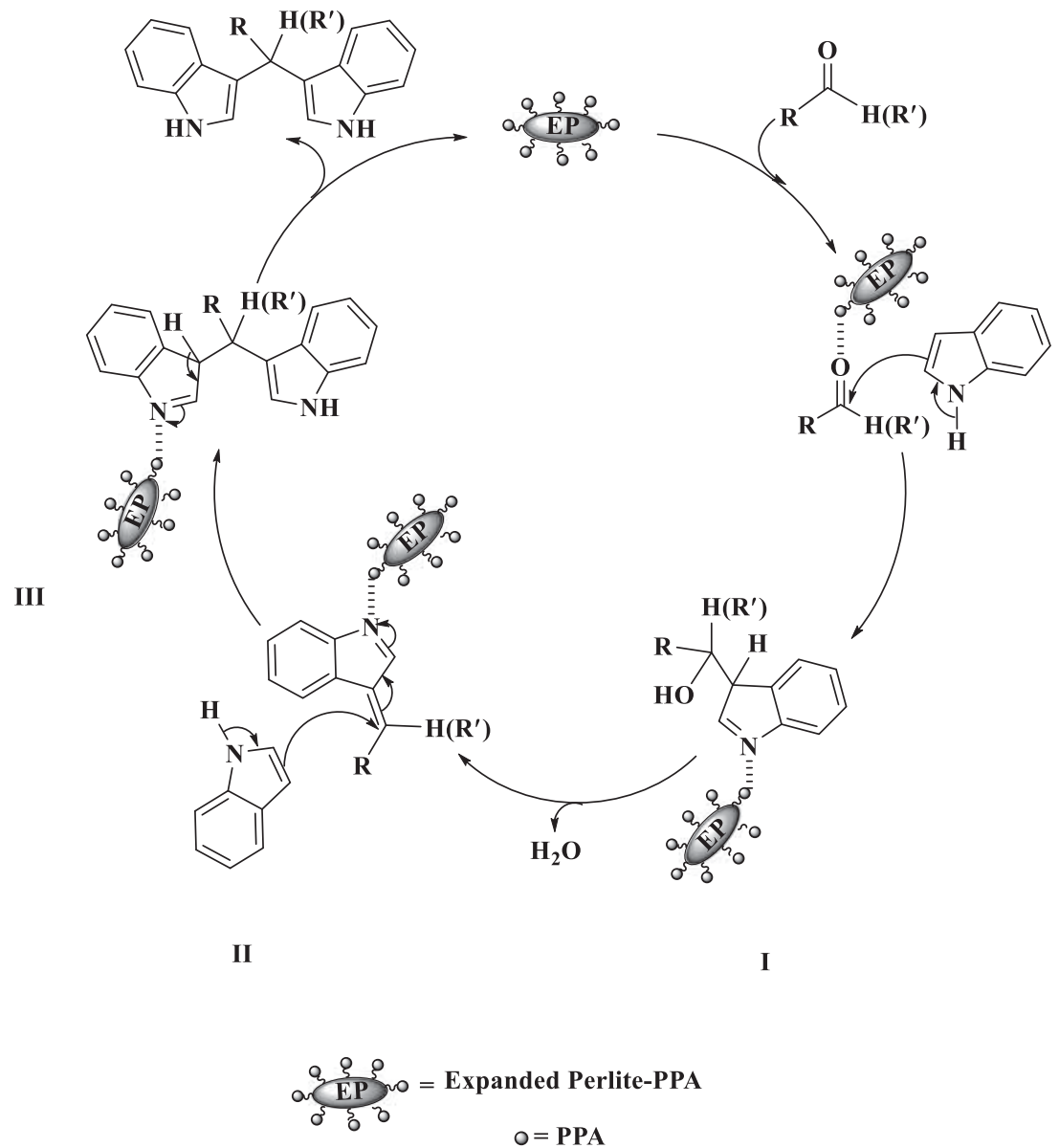

Scheme 3. Proposed mechanism for the preparation of aryl/alkylbis(indolyl)methanes in the presence of EP-PPA. 
Table 3. Synthesis of structurally different aryl/alkylbis(indolyl)methanes in the presence of EP-PPA.

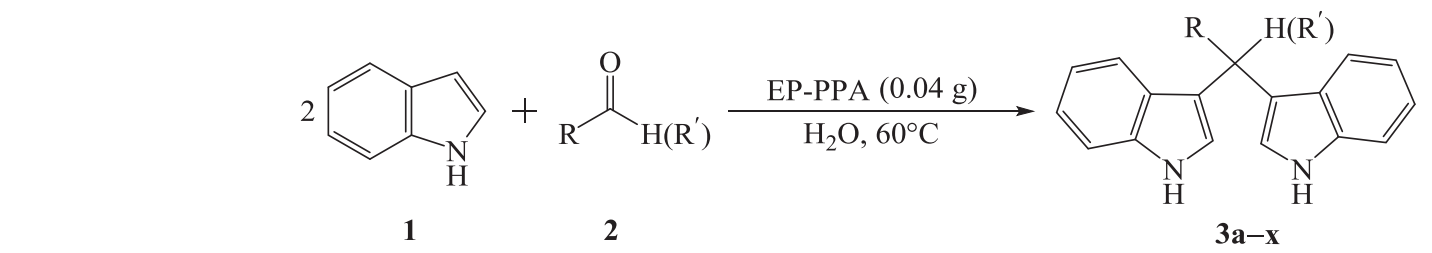

\begin{tabular}{|c|c|c|c|c|}
\hline Entry & Carbonyl compound & Product & Time/min & Isolated yield/\% \\
\hline
\end{tabular}

1<smiles>O=Cc1ccccc1</smiles><smiles>c1ccc(C(c2c[nH]c3ccccc23)c2c[nH]c3ccccc23)cc1</smiles><smiles>O=Cc1cccc([N+](=O)[O-])c1</smiles><smiles>O=[N+]([O-])c1cccc(C(c2c[nH]c3ccccc23)c2c[nH]c3ccccc23)c1</smiles><smiles>O=Cc1ccc([N+](=O)[O-])cc1</smiles><smiles>O=[N+]([O-])c1ccc(C(c2c[nH]c3ccccc23)c2c[nH]c3ccccc23)cc1</smiles><smiles>N#Cc1ccc(C=O)cc1</smiles><smiles>N#Cc1ccc(C(c2c[nH]c3ccccc23)c2c[nH]c3ccccc23)cc1</smiles><smiles>O=Cc1ccc(F)cc1</smiles><smiles>Fc1ccc(C(c2c[nH]c3ccccc23)c2c[nH]c3ccccc23)cc1</smiles> 
Table 3. (Continued)

6<smiles>O=Cc1ccccc1Cl</smiles><smiles>Clc1ccccc1C(c1c[nH]c2ccccc12)c1c[nH]c2ccccc12</smiles>

7<smiles>O=Cc1ccc(Cl)cc1</smiles><smiles>Clc1ccc(C(c2c[nH]c3ccccc23)c2c[nH]c3ccccc23)cc1</smiles><smiles>O=Cc1cccc(Br)c1</smiles><smiles>Brc1cccc(C(c2c[nH]c3ccccc23)c2c[nH]c3ccccc23)c1</smiles><smiles>Brc1ccc(C(c2c[nH]c3ccccc23)c2c[nH]c3ccccc23)cc1</smiles><smiles>O=Cc1cc(Br)ccc1O</smiles><smiles>Oc1ccc(Br)cc1C(c1c[nH]c2ccccc12)c1c[nH]c2ccccc12</smiles><smiles>Cc1cccc(C=O)c1</smiles><smiles>Cc1cccc(C(c2c[nH]c3ccccc23)c2c[nH]c3ccccc23)c1</smiles> 
Table 3. (Continued)

12<smiles>Cc1ccc(C=O)cc1</smiles>

13<smiles>O=Cc1ccccc1O</smiles>

14<smiles>O=Cc1ccc(O)cc1</smiles>

15<smiles>COc1ccc(C=O)cc1</smiles>

16<smiles>CN(C)c1ccc(C=O)cc1</smiles>

$\left.\square^{\mathrm{S}}\right\rangle^{\mathrm{CHO}}$<smiles>Cc1ccc(C(c2c[nH]c3ccccc23)c2c[nH]c3ccccc23)cc1</smiles>

31

30

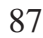<smiles>Oc1ccccc1C(c1c[nH]c2ccccc12)c1c[nH]c2ccccc12</smiles><smiles>Oc1ccc(C(c2c[nH]c3ccccc23)c2c[nH]c3ccccc23)cc1</smiles><smiles>COc1ccc(C(c2c[nH]c3ccccc23)c2c[nH]c3ccccc23)cc1</smiles><smiles>CN(C)c1ccc(C(c2c[nH]c3ccccc23)c2c[nH]c3ccccc23)cc1</smiles><smiles>c1csc(C(c2c[nH]c3ccccc23)c2c[nH]c3ccccc23)c1</smiles> 
Table 3. (Continued)

18<smiles>O=Cc1cccnc1</smiles>

19<smiles>O=Cc1cccc2ccccc12</smiles><smiles>O=C/C=C/c1ccccc1</smiles>

21<smiles>CCCCCCCC=O</smiles>

22<smiles>CCCCCC=O</smiles>

23<smiles>O=C1CCCCC1</smiles><smiles>O=C1Nc2ccccc2C1=O</smiles><smiles>c1cncc(C(c2c[nH]c3ccccc23)c2c[nH]c3ccccc23)c1</smiles><smiles>c1ccc2c(C(c3c[nH]c4ccccc34)c3c[nH]c4ccccc34)cccc2c1</smiles>

$3 s$

$20 \mathrm{~min} / 3 \mathrm{~h}$ $48 / 72$<smiles>C(=Cc1c[nH]c2ccccc12)c1c[nH]c2ccccc12</smiles><smiles>CCCCCCCC(c1c[nH]c2ccccc12)c1c[nH]c2ccccc12</smiles>

15<smiles>CCCCC(c1c[nH]c2ccccc12)c1c[nH]c2ccccc12</smiles>

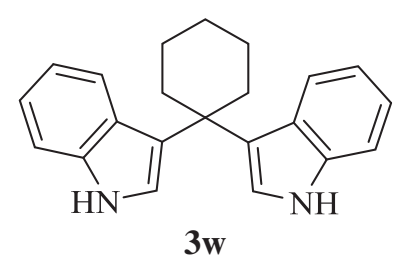<smiles>O=C1Nc2ccccc2C1(c1c[nH]c2ccccc12)c1c[nH]c2ccccc12</smiles>

$50 / 80$ 
although the corresponding reaction rates were diminished to some extent (Table 3, entries 17 and 18). Likewise, structurally hindered aldehydes (such as 1naphthaldehyde), cinnamaldehyde and aliphatic aldehydes (such as octanal and hexanal) reacted smoothly with indole to give the corresponding products in moderate yields (Table 3, entries 19-22). Further, we also examined the reaction of some ketones with indole, but the results were far from satisfactory. In the case of cyclohexanone and isatin, the reactions were not completed even after a prolonged reaction time and the best obtained yields of the products were low: 60 and $65 \%$, respectively (Table 3, entries 23, 24). Moreover, the electrophilic substitution reactions of ethyl methyl ketone, 2-heptanone, methyl vinyl ketone, isobutyl methyl ketone, and cyclopentanone with indole were also examined under the optimized condition, but the best obtained range of the products yields were only 10 $20 \%$, even after a long period of time (data are not given in Table 3). However, no product was obtained when aryl ketones such as acetophenone and propiophenone were used in this reaction under the same conditions (data are not given in Table 3). It can be concluded that the progress of this transformation was not convincing with ketones, which is most probably due to their lower reactivity as compared to the aldehydes.

Melting points of the obtained aryl/alkylbis(indolyl) methanes were closely matching with those reported in the literature. The FT-IR spectra of aryl/alkylbis(indolyl)methanes reveal the characteristic absorption bands at 3408-3367 (N-H), 2925-2922 (aliphatic C-H), 1617-1602 and 1455-1454 $\mathrm{cm}^{-1}$ (aromatic $\mathrm{C}=\mathrm{C}$ ). Moreover, ${ }^{1} \mathrm{H}$ NMR spectra confirmed the condensation reactions by the appearance of the characteristic signals at 8 7.9-7.73 (br s, NH), 5.9-5.74 (s, aliphatic $\mathrm{C}-\mathrm{H})$ and 7.03-6.54 (s, pyrrole C-H).
A plausible mechanism for the EP-PPA catalyzed synthesis of aryl/alkylbis(indolyl)methanes is shown in Scheme 3. In the initial step, EP-PPA activates the carbonyl group of the carbonyl compound, making it susceptible to attack by indole. Nucleophilic attack of indole to activated carbonyl compound leads to the formation of intermediate I, which generates II by losing water. Further addition of the second molecule of indole affords intermediate III, which then suffers a hydride shift to furnish aryl/alkylbis(indolyl)methanes formation. In the entire mechanism, EP-PPA was regenerated and reused for the consecutive runs.

Recyclability of the EP-PPA catalyst was checked for the model reaction of indole and benzaldehyde. After completion of the reaction, the catalyst was separated by filtration and then washed with deionized water and ethanol 3 times. The separated catalyst was dried at $50^{\circ} \mathrm{C}$ and utilized for subsequent preparation of 3,3'(phenylmethylene)bis( $1 H$-indole). The procedure was repeated six times without any significant loss of efficiency, as the catalyst remained active even after the sixth run and led to $84 \%$ yield of the product (Figure 5).

Furthermore, the FT-IR spectrum for the reused catalyst after 6 runs indicates that all of the characteristic peaks have been well preserved in terms of shape, position, and relative intensity. These results reveal that no significant changes have occurred in the chemical structure of functional groups and the hydrogen bonding network of the catalyst, during the reaction progress and multiple recovery operations.

The superior catalytic activity of EP-PPA compared with some other acidic catalysts for the synthesis of 3,3'-(phenylmethylene)bis( $1 H$-indole) was investigated and results are shown in Table 4. Among these catalysts, EP-PPA presents the best performance in this transformation, with respect to shorter reaction time,

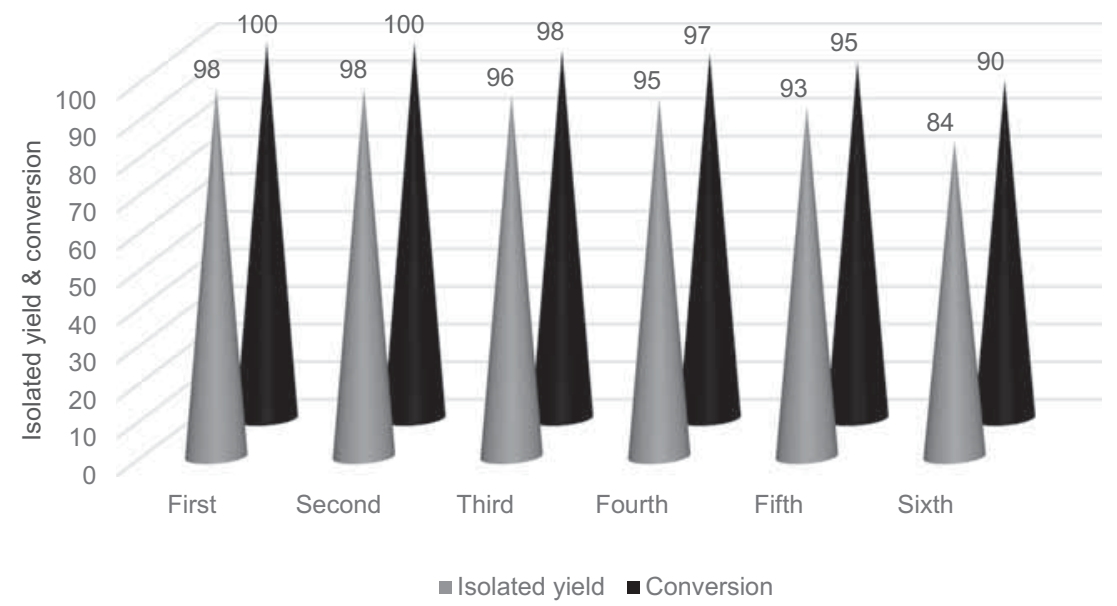

Figure 5. Synthesis of 3,3'-(phenylmethylene)bis( $1 H$-indole) in the presence of reused EP-PPA. 
Table 4. Comparison between the efficiency of EP-PPA and some other catalysts for the synthesis of 3,3'-(phenylmethylene)bis $(1 H$-indole).

\begin{tabular}{llcccc}
\hline Entry & \multicolumn{1}{c}{ Catalyst } & Solvent & Time/min & Yield/\% & Ref. \\
\hline 1 & Oxalic acid & $\mathrm{H}_{2} \mathrm{O}$ & 45 & 96 & 22 \\
2 & $\mathrm{H}_{6} \mathrm{P}_{2} \mathrm{~W}_{18} \mathrm{O}_{62}$ & - & 40 & 96 & 26 \\
3 & $\mathrm{Squaric} \mathrm{acid}_{4}$ & $\mathrm{H}_{2} \mathrm{O}$ & $3 / \mathrm{h}$ & 90 & 54 \\
4 & $\mathrm{HMTAB}^{\mathrm{a}}$ & $\mathrm{H}_{2} \mathrm{O}$ & $2.5 / \mathrm{h}$ & 86 & 55 \\
5 & $\mathrm{Cu}_{1.5} \mathrm{PMo}_{12} \mathrm{O}_{40}$ & $\mathrm{Ionic} \mathrm{liquid}$ & 10 & 95 & 56 \\
6 & $\mathrm{Cu}\left(\mathrm{BF}_{4}\right)_{2} \cdot \mathrm{SiO}_{2}$ & $\mathrm{CH}_{2} \mathrm{Cl}$ & 30 & 96 & 57 \\
7 & $\mathrm{Cu} / \mathrm{MWCNT}_{2}$ & 40 & 88 & 58 \\
8 & $\mathrm{Br}_{2}$ & $\mathrm{H}_{2} \mathrm{O}$ & $6 / \mathrm{hA} @ \mathrm{Fe}_{3} \mathrm{O}_{4}^{\mathrm{b}}$ & 93 & 59 \\
9 & EP-PPA & $\mathrm{H}_{2} \mathrm{O}$ & 10 & 98 & Present study \\
\hline
\end{tabular}

${ }^{a}$ Hexamethylenetetramine-bromine.

${ }^{\mathrm{b}}$ Copper nanocatalyst based on magnetic guanidine acetic acid (GAA) functionalized multi-wall carbon nanotube (MWCNT).

lower temperature, and higher yield. In addition, several of the previously reported procedures involved using toxic, non-recyclable, expensive chemicals or difficult and time-consuming synthesis-based catalysts, whereas the current catalyst shows unique advantages including simplification of the catalytic system and its synthesis, besides the application of inexpensive, natural, nontoxic, and availability of precursor to prepare the catalyst. Moreover, the presented green, recyclable and highly efficient heterogeneous catalyst is accompanied with ease of handling and a clean and mild reaction conditions, which are notable features that support this approach in a movement toward the green chemistry.

\section{Conclusions}

In conclusion, EP-PPA (an inexpensive and eco-friendly catalyst) was found to be an efficient catalyst for the electrophilic substitution reaction of indole with various carbonyl compounds to afford aryl/alkylbis(indolyl) methane derivatives in good to excellent yields. This method is applicable to a wide range of aldehydes and ketones. The merit of this methodology is that it is simple, mild, and efficient with excellent yields of products, shorter reaction times, simple operational procedure for purification of products, and recovery and reuse of the catalyst six times without considerable loss of efficiency. Another important feature of this methodology is using environmentally benign conditions such as applying stoichiometric amounts of reactants and avoidance of hazardous organic solvents. Therefore, we believe that the present methodology will find applications in organic synthesis and green chemistry.

\section{Supplementary Information (SI)}

Supplementary Information is available at www.ias.ac.in/ chemsci.

\section{Acknowledgements}

The authors gratefully acknowledge the partial support of this study by Ferdowsi University of Mashhad Research Council (Grant no. p/3/40471).

\section{References}

1. El-Gamal A A, Wang W L and Duh C Y 2005 Sulfurcontaining polybromoindoles from the Formosan red alga Laurencia brongniartii J. Nat. Prod. 68815

2. Endo T, Tsuda M, Fromont J and Kobayashi J 2007 Hyrtinadine A, a Bis-indole Alkaloid from a Marine Sponge J. Nat. Prod. 70423

3. Garbe T R, Kobayashi M, Shimizu N, Takesue N, Ozawa $\mathrm{M}$ and Yukawa H 2000 Indolyl carboxylic acids by condensation of indoles with $\alpha$-keto acids J. Nat. Prod. 63596

4. Sirisoma N, Pervin A, Drewe J, Tseng B and Cai S X 2009 Discovery of substituted N'-(2-oxoindolin3 -ylidene)benzohydrazides as new apoptosis inducers using a cell- and caspase-based HTS assay Bioorg. Med. Chem. Lett. 192710

5. Gribble G W (Ed.) 1996 Comprehensive heterocyclic chemistry (New York: Pergamom Press) p. 211

6. Frost J M, Dart M J, Tietje K R, Garrison T R, Grayson G K, Daza A V, El-Kouhen O F, Miller L N, Li L L, Yao B B, Hsieh G C, Pai M, Zhu C Z, Chandran P and Meyer M D 2008 Indol-3-yl-tetramethylcyclopropyl ketones: Effects of indole ring substitution on $\mathrm{CB}_{2}$ cannabinoid receptor activity J. Med. Chem. $\mathbf{5 1} 1904$

7. Morris S A and Anderson R J 1990 Brominated bis(indole) alkaloids from the marine sponge hexadella SP Tetrahedron Lett. $\mathbf{4 6} 715$

8. (a) Ramirez A and Garcia Rubio S 2003 Current progress in the chemistry and pharmacology of akuammiline alkaloids Curr. Med. Chem. 10 1891; (b) Tjalkens R B and Safe S 2013 Use of diindolylmethane (DIM) compounds and derivatives as neuroprotective agents U.S. patent 8580843

9. (a) Porter J K, Bacon C W, Robbins J D, Himmelsbach D S and Higman H C 1977 Indole alkaloids from Balansia epichloe (Weese) J. Agric. Food. Chem. 25 88; (b) Oh K B, Mar W, Kim S, Kim J Y, Lee T H, Kim 
J G, Shin D, Sim C J and Shin J 2006 Antimicrobial activity and cytotoxicity of bis(indole) alkaloids from the Sponge Spongosorites sp. Biol. Pharm. Bull. 29570 ; (c) Fahy E, Potts B C M, Faulkner D J and Smith K 1991 6-Bromotryptamine derivatives from the Gulf of California tunicate didemnum candidum J. Nat. Prod. 54564

10. Bell R, Carmeli S and Sar N 1994 Vibrindole A, a metabolite of the marine bacterium, vibrio parahaemolyticus, isolated from the toxic mucus of the boxfish ostracion cubicus J. Nat. Prod. 571587

11. Shankar M, Suvetha K, Kumarasamyraja D and Gowrishankar N L 2012 Synthesis and biological evaluation of novel pyrazolyl bis-indolylmethane Int. J. Pharm. Pharm. Sci. 4518

12. (a) Huang M T, Osawa $\mathrm{T}$, Ho $\mathrm{C} \mathrm{T}$ and Rosen $\mathrm{R} \mathrm{T}$ (Eds.) 1993 In Food phytochemicals for cancer prevention I (New Jersey: American Chemical Society) p. 17; (b) Zeligs M A 1998 Diet and estrogen status: The cruciferous connection J. Med. Food 167

13. (a) Bell M C, Crowley-Nowick P, Bradlow H L, Sepkovic D W, Schmidt-Grimminger D, Howell P, Mayeaux E J, Tucker A, Turbat-Herrera E A and Mathis J M 2000 Placebo-controlled trial of indole-3-carbinol in the treatment of CIN Gynecol. Oncol. 78 123; (b) Thomas C H 1985 Low cost polyester modified phenolic resin containing a combination of long and short chain alkylphenols U.S. patent 4500689

14. Kaishap P P and Dohutia C 2013 Synthetic approaches for bis(indolyl)methanes IJPSR 41312

15. Shiri M, Zolfigol M A, Kruger H G and Tanbakouchian Z 2010 Bis- and trisindolylmethanes (BIMs and TIMs) Chem. Rev. 1102250

16. Chakrabarty M, Ghosh N, Basak R and Harigaya Y 2002 Dry reaction of indoles with carbonyl compounds on montmorillonite K10 clay: A mild, expedient synthesis of diindolylalkanes and vibrindole A Tetrahedron Lett. 434075

17. Yadav J S, Reddy B V S and Satheesh G 2004 Montmorillonite clay catalyzed alkylation of pyrroles and indoles with cyclic hemi-acetals Tetrahedron Lett. $\mathbf{4 5}$ 3673

18. Zhang C L and Du Z Q 2009 Synthesis of bisindolylmethanes catalyzed by oxone Chin. Chem. Lett. 201411

19. Azizian J, Teimouri F and Mohamadizadeh M R 2007 Ammonium chloride catalyzed one-pot synthesis of diindolylmethanes under solvent-free conditions Catal. Commun. 81117

20. Alinezhad H, Haghighi A H and Salehian F 2010 A green method for the synthesis of bis-indolylmethanes and 3,3'-indolyloxindole derivatives using cellulose sulfuric acid under solvent-free conditions Chin. Chem. Lett. 21183

21. Das P J and Das J 2012 Synthesis of aryl/alkyl(2,2'-bis3-methylindolyl)methanes and aryl(3,3'-bis indolyl)methanes promoted by secondary amine based ionic liquids and microwave irradiation Tetrahedron Lett. $\mathbf{5 3} 4718$

22. Kokare N D, Sangshetti J N and Shinde D B 2008 Oxalic acid as a catalyst for efficient synthesis of bis(indolyl)methanes, and 14-aryl-14H-dibenzo[ $a, j]$ xanthenes in water Chin. Chem. Lett. 191186
23. Chen D, Yu L and Wang P G 1996 Lewis acid-catalyzed reactions in protic media. Lanthanide-catalyzed reactions of indoles with aldehydes or ketones Tetrahedron Lett. 374467

24. Ghosh R and Maiti S 2007 Advances in indium triflate catalyzed organic syntheses J. Mol. Catal. A: Chem. 2641

25. Zolfigol M A, Salehi P, Shiri M and Tanbakouchian Z 2007 A new catalytic method for the preparation of bis-indolyl and tris-indolyl methanes in aqueous media Catal. Commun. 8173

26. Heravi M M, Bakhtiari K, Fatehi A and Bamoharram F F 2008 A convenient synthesis of bis(indolyl)methanes catalyzed by diphosphooctadecatungstic acid Catal. Commun. 9289

27. Nadkarni S V, Gawande M B, Jayaram R V and Nagarkar J M 2008 Synthesis of bis(indolyl)methanes catalyzed by surface modified zirconia Catal. Commun. 91728

28. Satam J R, Parghi K D and Jayaram R V 2008 12Tungstophosphoric acid supported on zirconia as an efficient and heterogeneous catalyst for the synthesis of bis(indolyl)methanes and tris(indolyl)methanes Catal. Commun. 91071

29. Yadav J S, Reddy B V S, Padmavani B and Gupta M K 2004 Gallium(III) halide-catalyzed coupling of indoles with phenylacetylene: Synthesis of bis(indolyl)phenylethanes Tetrahedron Lett. 457577

30. Hosseini-Sarvari M 2008 Synthesis of bis(indolyl) methanes using a catalytic amount of $\mathrm{ZnO}$ under solvent-free conditions Synth. Commun. 38832

31. Ji S J, Zhou M F, Gu D G, Jiang Z Q and Loh T P 2004 Efficient Fe $\mathrm{III}^{\mathrm{III}}$-catalyzed synthesis of bis(indolyl) methanes in ionic liquids Eur. J. Org. Chem. 20041584

32. Sadaphal S A, Kategaonkar A H, Labade V B and Shingare M S 2010 Synthesis of bis(indolyl) methanes using aluminium oxide (acidic) in dry media Chin. Chem. Lett. 2139

33. Jafarpour M, Rezaeifard A and Golshani T 2009 A new catalytic method for ecofriendly synthesis of bisand trisindolylmethanes by zirconyldodecylsulfate under mild conditions J. Heterocycl. Chem. 46535

34. (a) Bandgar B P and Shaikh K A 2003 Molecular iodine-catalyzed efficient and highly rapid synthesis of bis(indolyl)methanes under mild conditions Tetrahedron Lett. 44 1959; (b) Ji S J, Wang S Y, Zhang Y and Loh T P 2004 Facile synthesis of bis(indolyl)methanes using catalytic amount of iodine at room temperature under solvent-free conditions Tetrahedron 602051

35. Mendes $\mathrm{S}$ R, Thurow S, Fortes M P, Penteado F, Lenardão E J, Alves D, Perin G and Jacob R G 2012 Synthesis of bis(indolyl)methanes using silica gel as an efficient and recyclable surface Tetrahedron Lett. 53 5402

36. Yang Q, Yin Z L, Ouyang B L and Peng Y Y 2011 Pyridinium tribromide catalyzed condensation of indoles and aldehydes to form bisindolylalkanes Chin. Chem. Lett. 22515

37. Boroujeni K P and Parvanak K 2011 Efficient and solvent-free synthesis of bis-indolylmethanes using silica gel supported aluminium chloride as a reusable catalyst Chin. Chem. Lett. 22939 
38. Veisi H, Maleki B, Eshbala F H, Veisi H, Masti R, Ashrafi S S and Baghayeri M 2014 In situ generation of Iron(III) dodecyl sulfate as Lewis acid-surfactant catalyst for synthesis of bisindolyl, tris-indolyl, di(bisindolyl), tri(bis-indolyl), tetra(bis-indolyl)methanes and 3-alkylated indole compounds in water $R S C A d v .4$ 30683

39. Ahad A, Farooqui M, Khan P M A and Farooqui M 2012 Efficient reusable solid supported acid catalyzed multicomponent condensation of indole with carbonyl compounds under thermally and solvent free conditions Int. J. Green Chem. Bioproc. 231

40. Kirti S, Kumar D, Kumar Mogha N, Singh V and Masram D T 2016 An efficient synthesis of bis(indolyl) methanes under solvent free condition using silica supported polyphosphoric acid $\left(\mathrm{PPA}-\mathrm{SiO}_{2}\right)$ as recyclable catalyst IJSTR 615

41. Mendes S R, Thurow S, Penteado F, da Silva M S, Gariani R A, Perin G and Lenardão E J 2015 Synthesis of bis(indolyl)methanes using ammonium niobium oxalate (ANO) as an efficient and recyclable catalyst Green Chem. 174334

42. Kobayashi S, Araki M and Yasuda M 1995 One-pot synthesis of $\beta$-amino esters from aldehydes using lanthanide triflate as a catalyst Tetrahedron Lett. 365773

43. Karthik M, Tripathi A K, Gupta N M, Palanichamy M and Murugesan V 2004 Zeolite catalyzed electrophilic substitution reaction of indoles with aldehydes: Synthesis of bis(indolyl)methanes Catal. Commun. 5371

44. (a) Baranova O V and Dubovitskii S V 2004 An unexpected rearrangement of 3-unsubstituted-2-acyl substituted indole phenylhydrazones. A new method for benz $[c] \beta$-carboline synthesis Tetrahedron Lett. 45 1299; (b) Mederski W W K R, Baumgarth M, Germann M, Kux D and Weitzel T 2003 A convenient synthesis of 4-aminoaryl substituted cyclic imides Tetrahedron Lett. 44 2133; (c) Dubovitskii S V 1996 Method for synthesis of 12H-pyrido[1,CR2-a:3,4-b']diindoles. Total synthesis of homofascaplysin C Tetrahedron Lett. 375207

45. (a) Razavi $\mathrm{N}$ and Akhlaghinia B $2015 \mathrm{Cu}$ (II) immobilized on aminated epichlorohydrin activated silica (CAES): As a new, green and efficient nanocatalyst for preparation of 5-substituted-1 $H$-tetrazoles $R S C A d v$. 5 12372; (b) Ghodsinia S S E and Akhlaghinia B 2015 A rapid metal free synthesis of 5-substituted$1 \mathrm{H}$-tetrazoles using cuttlebone as a natural high effective and low cost heterogeneous catalyst RSC Adv. 5 49849; (c) Zarghani M and Akhlaghinia B 2015 Copper immobilized on aminated ferrite nanoparticles by 2-aminoethyl dihydrogen phosphate $\left(\mathrm{Fe}_{3} \mathrm{O}_{4} @ \mathrm{AEPH}_{2}\right.$ $\mathrm{Cu}^{\mathrm{II}}$ ) catalyses the conversion of aldoximes to nitriles Appl. Organomet. Chem. 29 683; (d) Zarei Z and Akhlaghinia B 2015 Ce(III) immobilised on aminated epichlorohydrin-activated agarose matrix - "green" and efficient catalyst for transamidation of carboxamides Chem. Pap. - Chem. Zvesti 69 1421; (e) Zarghani M and Akhlaghinia B 2015 Sulfonated nanohydroxyapatite functionalized with 2-aminoethyl dihydrogen phosphate (HAP@AEPH$-\mathrm{AO}_{3} \mathrm{H}$ ) as a new recyclable and eco-friendly catalyst for rapid one-pot synthesis of 4,4'-(aryl methylene)bis(3-methyl-1 $H$-pyrazol-5-ol)s RSC Adv. 5 87769; (f) Razavi N and Akhlaghinia B 2016
Hydroxyapatite nanoparticles (HAP NPs): A green and efficient heterogeneous catalyst for three-component one-pot synthesis of 2,3-dihydroquinazolin-4(1H)-one derivatives in aqueous media New J. Chem. 40 447; (g) Jahanshahi R and Akhlaghinia B 2015 Expanded perlite: An inexpensive natural efficient heterogeneous catalyst for the green and highly accelerated solvent-free synthesis of 5-substituted-1H-tetrazoles using [bmim] $\mathrm{N}_{3}$ and nitriles $R S C A d v .5$ 104087; (h)Yousefi Siavashi N, Akhlaghinia B and Zarghani M 2016 Sulfonated nanohydroxyapatite functionalized with 2-aminoethyl dihydrogen phosphate ( $\mathrm{HAP} @ \mathrm{AEPH}_{2}-\mathrm{SO}_{3} \mathrm{H}$ ) as a reusable solid acid for direct esterification of carboxylic acids with alcohols Res. Chem. Intermed. 42 5789; (i) Karimian E, Akhlaghinia B and Ghodsinia S S E 2016 An efficient and convenient synthesis of $N$-substituted amides under heterogeneous condition using $\mathrm{Al}\left(\mathrm{HSO}_{4}\right)_{3}$ via Ritter reaction J. Chem. Sci. 128 429; (j) Jahanshahi $\mathrm{R}$ and Akhlaghinia B $2016 \mathrm{Cu}^{\mathrm{II}}$ immobilized on guanidinated epibromohydrin functionalized $\gamma-\mathrm{Fe}_{2} \mathrm{O}_{3} @ \mathrm{TiO}_{2}$ $\left(\gamma-\mathrm{Fe}_{2} \mathrm{O}_{3} @ \mathrm{TiO}_{2}-\mathrm{EG}-\mathrm{Cu}^{\mathrm{II}}\right)$ : A novel magnetically recyclable heterogeneous nanocatalyst for the green onepot synthesis of 1,4-disubstituted 1,2,3-triazoles through alkyne-azide cycloaddition in water RSC Adv. 6 29210; (k) Zarghani M and Akhlaghinia B 2016 Magnetically separable $\mathrm{Fe}_{3} \mathrm{O}_{4} @$ chitin as an eco-friendly nanocatalyst with high efficiency for green synthesis of 5-substituted$1 \mathrm{H}$-tetrazoles under solvent-free conditions $R S C A d v .6$ 31850; (1) Ghodsinia S S E, Akhlaghinia B and Jahanshahi R 2016 Direct access to stabilized $\mathrm{Cu}^{\mathrm{I}}$ using cuttlebone as a natural-reducing support for efficient $\mathrm{CuAAC}$ click reactions in water $R S C A d v .6$ 63613; (m) Zarghani M and Akhlaghinia B 2016 Green and efficient procedure for Suzuki-Miyaura and Mizoroki-Heck coupling reactions using palladium catalyst supported on phosphine functionalized $\mathrm{ZrO}_{2}$ NPs $\left(\mathrm{ZrO}_{2} @ \mathrm{ECP}-\mathrm{Pd}\right)$ as a new reusable nanocatalyst Bull. Chem. Soc. Jpn. 89 1192; (n) Masjed S M, Akhlaghinia B, Zarghani M and Razavi N 2016 Direct synthesis of nitriles from aldehydes and hydroxylamine hydrochloride catalyzed by a HAP@ $\mathrm{AEPH}_{2}-\mathrm{SO}_{3} \mathrm{H}$ nanocatalyst Aust. J. Chem. doi: 10.1071/CH16126; (o) Zarei Z and Akhlaghinia B $2016 \mathrm{Zn}$ (II) anchored onto the magnetic natural hydroxyapatite $\left(\mathrm{Zn}^{\mathrm{II}} / \mathrm{HAP} / \mathrm{Fe}_{3} \mathrm{O}_{4}\right)$ : As a novel, green and recyclable catalyst for $\mathrm{A}^{3}$-coupling reaction towards propargylamine synthesis under solvent-free conditions RSC Adv. 6 106473; (p) Razavi N, Akhlaghinia B and Jahanshahi R 2017 Aminophosphine Palladium(0) complex supported on $\mathrm{ZrO}_{2}$ nanoparticles $\left(\mathrm{ZrO}_{2} @ \mathrm{AEPH}_{2}-\mathrm{PPh}_{2}-\mathrm{Pd}(0)\right)$ as an efficient heterogeneous catalyst for Suzuki-Miyaura and Heck-Mizoroki reactions in green media Catal. Lett. 147 360; (q) Jahanshahi R and Akhlaghinia B 2017 Sulfonated Honeycomb Coral (HC-SO3H): A new, green and highly efficient heterogeneous catalyst for the rapid one-pot pseudo-five component synthesis of 4,4'-(aryl methylene) bis(3-methyl-1H-pyrazol-5-ol)s Chem. Pap. doi: 10.1007/s11696-016-0127-y

46. Akcam O and Karaca E 2013 J. Text. Apparel. 23233

47. (a) Erdem $\mathrm{T} \mathrm{K}$, Meral C, Tokyay M and Erdogan T Y 2007 Use of perlite as a pozzolanic addition in producing blended cements Cem. Concr. Compos. 29 13; 
(b) Hosseini $\mathrm{S} \mathrm{N}$, Borghei $\mathrm{S} \mathrm{M}$, Vossoughi $\mathrm{M}$ and Taghavinia N 2007 Immobilization of $\mathrm{TiO}_{2}$ on perlite granules for photocatalytic degradation of phenol Appl. Catal B: Environ. 74 53; (c) Sengul O, Azizi S, Karaosmanoglu F and Tasdemir M A 2011 Effect of expanded perlite on the mechanical properties and thermal conductivity of lightweight concrete Energy Build. 43 671; (d) Yilmazer S and Ozdeniz M B 2005 The effect of moisture content on sound absorption of expanded perlite plates Build Environ. 40 311; (e) Roulia M, Chassapis K, Kapoutsis J A, Kamitsos E I and Savvidis T 2006 Influence of thermal treatment on the water release and the glassy structure of perlite $J$. Mater. Sci. 41 5870; (f) Acosta D, Martinez J, Carrera C, Erdmann E, Gonzo E and Destéfanis H 2006 New material as support for nickel boride catalyst Lat. Am. Appl. Res. 36317

48. (a) Nasrollahzadeh M, Sajadi S M, Rostami-Vartooni A, Bagherzadeh M and Safari R 2015 Immobilization of copper nanoparticles on perlite: Green synthesis, characterization and catalytic activity on aqueous reduction of 4-nitrophenol J. Mol. Catal. A: Chem. 400 22; (b) Kolvari E, Koukabi N and Hosseini M M 2015 Perlite: A cheap natural support for immobilization of sulfonic acid as a heterogeneous solid acid catalyst for the heterocyclic multicomponent reaction J. Mol. Catal. A: Chem. 397 68; (c) Kolvari E, Koukabi N, Hosseini M M and Khandani Z 2015 Perlite: An inexpensive natural support for heterogenization of $\mathrm{HBF}_{4} R S C A d v .5$ 36828; (d) Sahraeian R, Hashemi S A, Esfandeh M and Ghasemi I 2012 Preparation of nanocomposites based on LDPE/Perlite: Mechanical and morphological studies Polym. Polym. Compos. 20 639; (e) Thanh D N, Singh M, Ulbrich P, Strnadova N and Stepanek F 2011 Perlite incorporating $\gamma-\mathrm{Fe}_{2} \mathrm{O}_{3}$ and $\alpha-\mathrm{MnO}_{2}$ nanomaterials: Preparation and evaluation of a new adsorbent for As(V) removal Sep. Purif. Technol. 82 93; (f) Skubiszewska-Zięba J, Charmas B, Leboda R and Gun'ko V M 2012 Carbon-mineral adsorbents with a diatomaceous earth/perlite matrix modified by carbon deposits Micropor. Mesopor. Mat. 156 209; (g) Hasan S, Ghosh T K, Viswanath D S and Boddu V M 2008 Dispersion of chitosan on perlite for enhancement of copper(II) adsorption capacity J. Hazard. Mater. 152 826

49. Majouli A, Alami Younssi S, Tahiri S, Albizane A, Loukili H and Belhaj M 2011 Characterization of flat membrane support elaborated from local Moroccan Perlite Desalination 27761

50. Sodeyama K, Sakka Y and Kamino Y 1999 Preparation of fine expanded perlite J. Mater. Sci. 342461

51. (a) Silverstein R M, Bassler G C and Morrill T C (Eds.) 1963 In Spectrometric identification of organic Compounds (New York, USA: Wiley) p. 162; (b) Pavia D L, Lampman G M, Kriz G S and Vyvyan J A (Eds) 2009 In Introduction to spectroscopy $4^{\text {th }}$ ed (Brooks/Cole: Belmont) Vol. 43 Ch. 2 p. 84; (c) Ahsan M R, Uddin M A and Mortuza M G 2005 Infrared study of the effect of $\mathrm{P}_{2} \mathrm{O}_{5}$ in the structure of lead silicate glasses Indian J. Pure Appl. Phys. 4389

52. Titus E, Ali N, Cabral G, Gracio J, Ramesh Babu $P$ and Jackson M J 2006 Chemically functionalized carbon nanotubes and their characterization using thermogravimetric analysis, fourier transform infrared, and raman spectroscopy J. Mater. Eng. Perform. 15182

53. Li C J and Chan T H (Eds.) 1997 In Organic reaction in aqueouse media (New York, USA: Wiley)

54. Azizi N, Gholibeghlo E and Manocheri Z 2012 Green procedure for the synthesis of bis(indolyl)methanes in water Sci. Iran. 19574

55. Teimouri M B and Mivehchi H 2005 Efficient hexamethylenetetramine-bromine (HMTAB)-catalyzed synthesis of bis(indolyl)methanes in water Synth. Commun. 351835

56. Seyedi N, Khabazzadeh H and Saidi K 2009 $\mathrm{Cu}_{1.5} \mathrm{PMo}_{12} \mathrm{O}_{40}$ as an efficient, mild and heterogeneous catalyst for the condensation of indole with carbonyl compounds Mol. Divers. 13337

57. Meshram G A and Patil V D 2009 Simple and efficient method for synthesis of bis(indolyl)methanes with $\mathrm{Cu}\left(\mathrm{BF}_{4}\right)_{2} \cdot \mathrm{SiO}_{2}$ under mild conditions Synth. Commun. 4029

58. Shaabani A, Afshari R, Hooshmand S E, Tavousi Tabatabaei A and Hajishaabanha F 2016 Copper supported on MWCNT-guanidine acetic acid@ $\mathrm{Fe}_{3} \mathrm{O}_{4}$ : Synthesis, characterization and application as a novel multi-task nanocatalyst for preparation of triazoles and bis(indolyl)methanes in water $R S C A d v .6$ 18113

59. Liang D, Huang W, Yuan L, Ma Y, Ma J and Ning D 2014 An underrated cheap Lewis acid: Molecular bromine as a robust catalyst for bis(indolyl)methanes synthesis Catal. Commun. 5511 